\title{
PENGEMBANGAN KEMAMPUAN BERPIKIR KREATIF MAHASISWA MELALUI PEMBELAJARAN BERBASIS PROYEK PADA MATA KULIAH KIMIA LINGKUNGAN DI MASA PANDEMIC COVID 19
}

\author{
Syarifa Wahidah Al-Idrus ${ }^{1}$, Muti'ah ${ }^{2}$, R. Rahmawati ${ }^{3}$ \\ Universitas Mataram \\ syarifaidrus@unram.ac.id
}

\begin{abstract}
This research aims to develop students' creative thinking skills. This study used a classroom research method with a one-shot case study design. The sample in this study were students of environmental chemistry at the Chemistry Education Study Program, FKIP UNRAM. Observation data will be obtained based on observation sheets to describe student activities and creativity from the beginning of the project to the end of the project. The project that is given focuses on environmental pollution material. The results of this study indicate that students are very active in the project-based learning process. Students' creative thinking skills in designing simple experiments about environmental pollution are in a good and very good position. The generating stage with a value of 90 (very good), the planning stage with a value of 88 (very good), the producing / producing stage is very good (88), the checking stage 80 is good, and the critiquing stage with a value (Good).
\end{abstract}

Keywords: Creative Thinking, Project-Based Learning, Chemistry, Covid 19

\begin{abstract}
Abstrak : Peneltian ini bertujuan untuk mengembangkan kemampuan berpikir kreatif mahasiswa. Penelitian ini menggunakan metode penelitian kelas dengan design one-shot case study. Sampel dalam penelitian ini adalah mahasiswa kimia lingkungan pada Program studi Pendidikan kimia FKIP UNRAM. Data pengamatan akan diperoleh berdasarkan lembar observasi untuk mendeskripsikan aktivitas dan kreatifitas mahasiswa mulai dari awal proyek sampai akhir proyek. Proyek yang diberikan focus pada materi pencemaran lingkungan. Hasil penelitian ini menunjukkan bahwa mahasiswa sangat aktif dalam proses pembelajaran berbasis proyek. Kemampuan berpikir kreatif mahasiswa dalam merancang percobaan sederhana tentang pencemaran lingkungan berada pada posisi baik dan sangat baik. Tahap membuat /generating dengan nilai 90 (sangat baik), tahap merencanakan/planning dengan nilai 88 (sangat baik), tahap memproduksi/producing sangat baik (88), tahap memeriksa (checking) 80 baik, dan tahap mengkritik (critiquing) dengan nilai 78 (baik).
\end{abstract}

As-Sabiqun : Jurnal Pendidikan Islam Anak Usia Dini

Volume 3, Nomor 1, Maret 2021; 14-25

https:/ / journal.stitpn.ac.id/index.php/assabiqun 


\section{PENDAHULUAN}

Kimia lingkungan merupakan salah satu Mata Kuliah yang ada dalam Program Studi Pendidikan Kimia FKIP Mataram. Kimia lingkungan merupakan bidang keilmuan yang membahas fenomena-fenomena kimia yang terjadi di alam akibat aktivitas manusia ${ }^{1}$. Masalah-masalah lingkungan, seperti polusi lingkungan, peningkatan populasi yang cepat, pemanasan global dan perubahan iklim, perusakan vegetasi alam dan sumber daya bumi, berkurangnya area pertanian dan sumber daya air, penghancuran lapisan ozon serta penurunan keanekaragaman hayati ${ }^{2}$. Masalah lingkungan dan semua dampak yang akan ditimbulkankan perlu dipahami oleh peserta didik terutama mahasiswa, sehingga ada upaya penyelesaian masalah ${ }^{3}$. Jika masalah lingkungan yang menyangkut prinsip keadilan sosial dan lingkungan dapat dihadirkan dalam pembelajaran kimia, tentu akan memberikan kerangka kerja untuk mengurangi dampak yang ditimbulkan, serta menjadikan peserta didik sebagai generasi paham kimia yang dapat mengupayakan keseimbangan lingkungan di masa depan ${ }^{4}$. Masalah lingkungan merupakan masalah penting yang bisa diselesaikan dengan kreatifitas setiap individu yang ada disekitarnya. Kreativitas diperlukan pada setiap bidang kehidupan untuk mendesain sesuatu, mengkreasi perubahan, menyelesaikan masalah yang bertujuan untuk meningkatkan kualitas hidup. Kemampuan pemecahan masalah, berpikir kritis dan berpikir kreatif merupakan hakekat tujuan pendidikan dan menjadi kebutuhan bagi mahasiswa untuk menghadapi dunia nyata ${ }^{5}$. Karena itu pengembangan berfikir kreatif sangat perlu dikembangkan pada mahasiswa kimia lingkungan sebagai upaya untuk menyelesaikan masalah masalah lingkungan.

${ }^{1}$ Manahan, E. S. (2010). Enviromental Chemistry. 9th ed. USA: CRC Press.

23 Gunter, Tugce; Akkuzu, Nalan; Alpat, S. (2017). Understanding 'green chemistry' and 'sustainability': an example of problem-based learning (PBL). Research in Science \& Technological Education, 35(4), 500-520

${ }^{4}$ Lasker, G. A., \& Brush, E. J. (2019). Integrating social and environmental justice into the chemistry classroom: a chemist's toolbox. Green Chemistry Letters and Reviews, 12(2), 168-177. https://doi.org/10.1080/17518253.2019.1609602

5 Santyasa, I. W. (2004). Model problem solving dan reasoning sebagai alternatif pembelajaran inovatif. Makalah. Disajikan dalam Konvensi Nasional Pendidikan Indonesia V. Bali: IKIP Negeri Singaraja. 
Kreativitas adalah hasil yang diperoleh dari terlatihnya kemampuan berpikir kreatif. Kemampuan berpikir kreatif dapat membangkitkan proses berfikir menemukan gagasan dan ide baru dalam menyelesaikan suatu masalah ${ }^{6}$. Selama ini di dalam proses Pendidikan lebih banyak mengembangkan pemecahan masalah, keterampilan berpikir kritis, dan keterampilan proses sains, sedangkan dalam mengembangkan kemampuan berpikir kreatif mahasiswa masih sangat rendah. Pembelajaran kimia lingkungan yang sebagian besar membahas tentang masalah lingkungan membutuhkan kreatifitas yang tinggi. Pembelajaran kimia lingkungan sering dianggap berkonotasi dengan pencemaran lingkungan yang disebabkan industri kimia dan penggunaan bahan kimia yang salah ${ }^{7}$. Selain itu pembelajaran kimia yang didukung oleh metode praktikum masih menggunakan lembar kerja yang sudah disiapkan oleh dosen, sehingga tidak melatih kreatifitas mahasiswa. Selain itu, berdasarkan beberapa hasil penelitian, proses pembelajaran kimia lingkungan diperguruan tinggi masih bersifat teoritis sehingga menghambat munculnya kreatifitas mahasiswa. Materi kimia lingkungan seringkali menggunakan strategi pembelajaran yang meliputi model, metode, dan pendekatan yang bersifat teoritis ${ }^{8}$.

Strategi pembelajaran yang bersifat teoritis menyebabkan mahasiswa tidak mampu merespons masalah-masalah lingkungan yang terjadi saat ini, mahasiswa masih lemah dalam hal kemampuan berpikir. Sementara Pembelajaran kimia lingkungan menuntut mahasiswa peka terhadap masalah lingkungan sekitar dan bertanggung jawab untuk menjaga keseimbangan lingkungan dan mengetahui hal hal yang akan memengaruhi populasi dan lingkungan ${ }^{9}$. Pembelajaran kimia lingkungan membutuhkan pendekatan pedagogis yang memberikan banyak momen pengajaran meliputi; tantangan penyelidikan, kuantisasi tingkat rendah dalam sampel lingkungan,

${ }^{6}$ Sastrika, I. A. K., Sadia, I. W., \& Muderawan, I. W. (2013). Pengaruh model pembelajaran berbasis proyek terhadap pemahaman konsep kimia dan keterampilan berpikir kritis. E-Journal Program Pascasarjana Universitas Pendidikan Ganesha, 3(2), 194-204.

${ }^{7}$ Ryu, Minjung; Nardo, J. E. . M. W. . M. Y. (2018). An examination of preservice elementary teachers' representation about chemistry in an in an intertextuality- and modeling-based course. Chemistry Education Research and Practice, 19(3), 681-693. doi: 10.1039/C7RP00150A

8 Sevian, H., \& Talanquer, V. (2014). Rethinking chemistry: A learning progression on chemical thinking. Chemistry Education Research and Practice, 15(1), 10-23. https://doi.org/10.1039/c3rp00111c

${ }^{9}$ Avellar, Isa G.J. de; Cotta, Tais A.P. G.; Neder, A. de V. F. (2012). Using Artificial Soil and DryColumn Flash Chromatography To Simulate Organic Substance Leaching Process: A Colorful Environmental Chemistry Experiment. J. Chem. Educ., 89(2), 248-253 
serta peluang pengembangan keterampilan kerja kelompok ${ }^{10}$. Oleh karena itu, pembelajaran kimia lingkungan perlu melakuakan perubahan dalam model pembelajaran terutama dalam metode praktikum yang diterapkan. Dalam penelitian ini digunakan model pembelajaran berbasis proyek yang akan diterapkan dalam metode paktikum kimia lingkungan.

Salah satu cara mengembangkan kemampuan berpikir kreatif pada mahasiswa yaitu dengan menerapkan Lembar Kerja berbasis proyek pada metode praktikum. Lembar kerja berbasis proyek ini diterapkan pada materi pencemaran lingkungan. Pencemaran lingkungan merupakan materi pokok kimia lingkungan yang sangat penting untuk dipahami. Pencemaran lingkungan meliputi; pencemaran air, tanah, dan udara sangat relevan dengan model pembelajaran berbaris proyek karena berkaitan dengan keseharian mahasiswa, serta bermanfaat bagi kehidupan manusia. Contoh masalah-masalah pencemaran lingkungan yang dapat diangkat menjadi proyek, yaitu pencemaran air di sekitar tempat tinggal, pencemaran tanah di akibat pembuangan sampah, dan pencemaran udara di sekitar kawasan PLTU, terminal dan jalanan yang padat. Mahasiswa diminta untuk merancang proyek kelompok, mulai dari menidentifikasi pencemaran yang ada di lingkungan sekitar, merancang percobaan sederhana untuk membuktikan pencemaran, mengidentifikasi penyebab pencemaran dan memberikan rekomendasi mencegah dan mengatasi pencemaran tersebut. Harapan dari model pembelajaran berbasis proyek ini mahasiswa mengalami peningkatan kreatifitas sehingga dapat menyelesaikan masalah masalah lingkungan yang ada disekitar mereka. Dengan demikian, model pembelajaran proyek dapat digunakan pada pembelajaran kimia lingkungan untuk menumbuhkan kemampuan berpikir kreatif mahasiswa. Selain itu pembelajaran berbasis proyek merupakan alternative model pembelajaran yang sangat tepat dilakukan dimasa pandemic covid 19. Berdasarkan SE Mendikbud no.4/2020 membuat pusat pendidikan melakukan pembelajaran dari rumah untuk para peserta didik, dan dengan segala keterbatasan BDR harus bisa menghasilkan pembelajaran bermakna.

\footnotetext{
10 Davis, Eric J.; Pauls, Steve; Dick, J. (2017). Project-Based Learning in Undergraduate Environmental Chemistry Laboratory: Using EPA Methods To Guide Student Method Development for Pesticide Quantitation. J. Chem. Educ, 94(4), 451-457.
} 
Pembelajaran bermakna dapat diwujudkan dengan memilih model pembelajaran yang tepat. Pada masa pandemic covid 19, pembelajaran dilakukan secara daring, sehingga dibutuhkan model pembelajaran yang dapat mengaktifkan mahasiswa. Model pembelajaran berbasis proyek atau Project Based Learning yang disebutkan oleh Mendikbud merupakan salah satu alternative yang bisa digunakan oleh guru dan dosen untuk meningktakan keaktifan, kreatifitas dan kemandirian peserta didik. Model pembelajaran berbasis proyek adalah model pembelajaran yang dapat digunakan untuk mengaplikasikan materi yang sudah diberikan dan melatih berbagai keterampilan berpikir kreatif, sikap dalam kerjasama, dan keterampilan yang nyata. Penerapan model pembelajaran berbasis proyek diharapkan melatih kemandirian, kerjasama dan eksperimen dalam diri mahasiswa

\section{METODE PENELITIAN}

Penelitian ini menggunakan metode penelitian kelas dengan design one-shot case study, dengan memberikan lembar kerja berbasis proyek yang akan menghasilkan suatu produk. focus tindakan dalam desain penelitian ini terhadap subyek adalah 1 kali perlakuan. Subyek diberikan perlakuan dan selanjutnya diobservasi hasilnya ${ }^{11}$. Produk yang diharapkan berupa laporan hasil proyek yang telah dirancang dan diamati. Hasil pengamatan akan dipresentasikan didepan kelas.

Data pengamatan akan diperoleh berdasarkan lembar observasi untuk mendeskripsikan aktivitas mahasiswa mulai dari awal proyek sampai akhir proyek. Cek list dari Lembar kerja berbasis proyek yang diperoleh akan diubah menjadi nilai persentase $^{12}$. LK berbasis proyek digunakan untuk mengamatai setiap tahap proyek yang dilakukan dimana didalamnya terdapat wacana serta alat dan bahan. LK ini sebelum peroses turun lapangan di konsultasikan pada dosen pengampu dan dipresentasikan untuk mendapatkan masukan. LK ini dibuat sebagai salah satu alat ukur untuk mengetahui kemampuan berpikir kreatif mahasiswa. Pada LK ini berisi tahapan-tahapan yang sesuai dengan pembelajaran berbasis proyek yang disesuaikan dengan indikator keterampilan berpikir kreatif. Analisis data selanjutnya yaitu

${ }^{11}$ Sugiyono. (2017). Metode Penelitian Kuantitatif, Kualitatif dan R\&D. Bandung: CV. Alfabeta 12,13 Arikunto, S. (2010). Dasar-Dasar Evaluasi Pendidikan. Jakarta: Bumi Aksara, 2012 
menggunakan penilaian hasil pengamatan dengan mengubah skor menjadi nilai ${ }^{13}$. Penilaian hasil proyek digunakan untuk mengukur kemampuan berpikir kreatif mahasiswa pada pembuatan rancangan percobaan mengenai pencemaran lingkungan. Adapun format penilaian hasil proyek dilakukan dengan lembar penilaian tersebut berupa daftar cek list ${ }^{14}$.

\section{HASIL DAN PEMBAHASAN}

Hasil penelitian ini menunjukkan bahwa mahasiswa sangat aktif dalam proses pembelajaran berbasis proyek. Hal ini terlihat hampir semua mahasiswa aktif dalam menyelesaikan proyek yang telah ditugaskan. Dengan pembelajaran berbasis proyek ini mahasiswa dituntut untuk aktif menyelesaikan proyek di lapangan, sehingga keaktifan juga akan muncul disaat proses pembelajaran langsung. Adapun tahapan tahapan pembelajaran proyek yang memancing aktivitas dan kreatifitas mahasiswa adalah sebagai berikut; 1. Penyajian suatu permasalahan yang disampaikan melalui pertanyaan. 2. Membuat perencanaan. Menentukan standar kompetensi yang akan di sampaikan dan dikaji ketika membahas permasalahan. 3. Penyusunan jadwal pelaksanaan proyek yang disepakati bersama. 4. Melakukan monitoring terhadap perkembangan pembuatan proyek, dapat dilakukan melalui presentasi setiap kelompok yang selanjutnya akan mendapatkan masukan dari kelompok lain. 5. Melakukan penilaian autentik, dan dilakukan verifikasi. 6. Melakukan evaluasi dan memberikan kesempatan kepada peserta didik untuk melakukan refleksi pembelajaran yang telah dilakukan baik secara individu maupun kelompok ${ }^{15}$.

Dalam penelitian ini merujuk tahapan tahapan yang telah dikembangkan oleh Nuswowati mengenai pencemaran lingkungan, yaitu 1) Mendeteksi, mengenali, dan memahami serta menanggapi adanya masalah pencemaran disekitar mahasiswa; 2) Menduga sumber pencemar dan dampak nya, jika tidak segera diatasi; 3) Mempertimbangkan pemecahan atau pendekatan terhadap masalah pencemaran yang telah ada; 4) Mampu mencetuskan gagasan dengan cara-cara yang asli dan secara

\footnotetext{
${ }^{14}$ Farida, I. (2017). Evaluasi Pembelajaran. Bandung: PT. Remaja Rosdakarya, 2017.

15 Sani, R. A. (2014). Pembelajaran Saintifik untuk Implementasi Kurikulum 2013. Jakarta: Bumi Aksara.
} 
green chemistry dalam menyelesaikan masalah dan merancang percobaan sederhana; 5) Mampu membuat laporan dan memperesentasikan hasil secara detail.

Kemampuan berpikir kreatif mahasiswa melalui pembelajaran berbasis proyek pada pembuatan rancangan percobaan sederhana untuk mengetahui pencemaran lingkungan dapat terlihat pada grafik dibawah:.

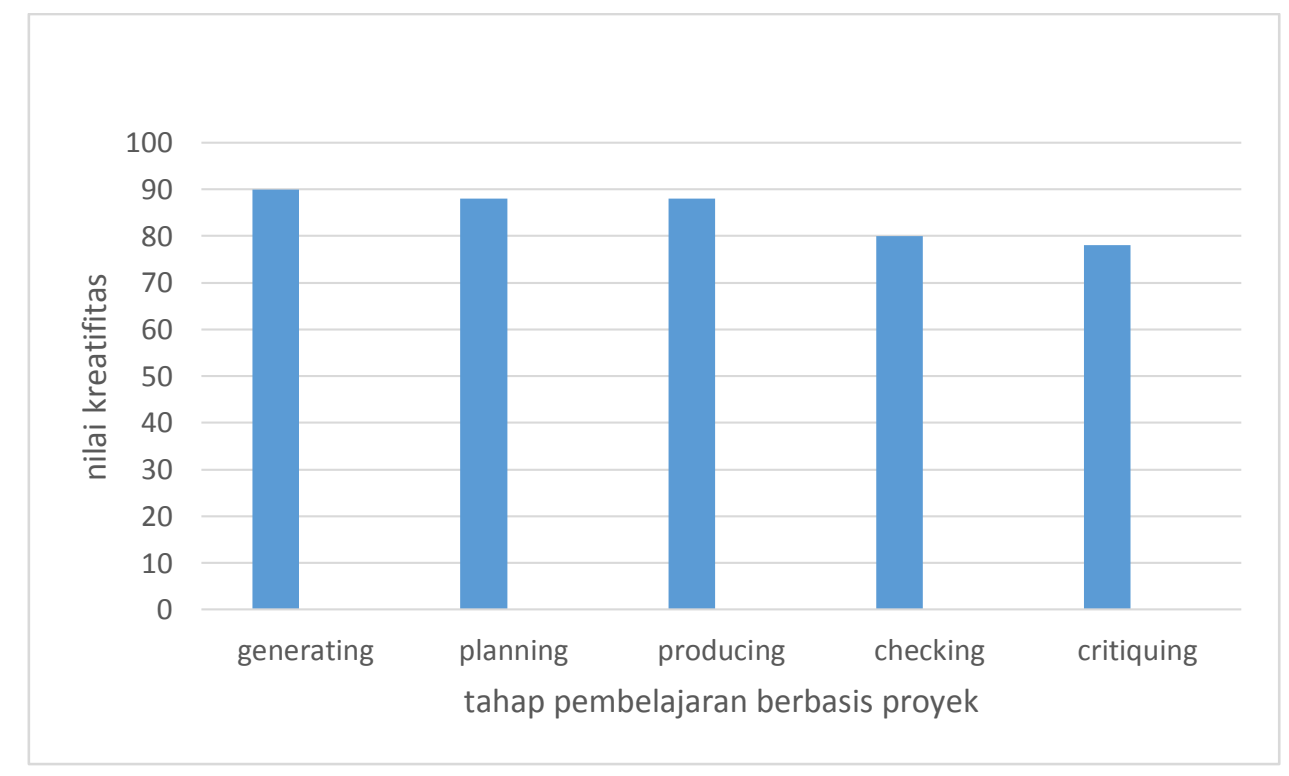

Gambar 1. Nilai kreatifitas mahasiswa pada tahapan pembelajaran proyek

Berdasarkan grafik 1, tahapan tahapan pembelajaran berbasis proyek pada mata kuliah kimia lingkungan untuk mengembangkan kemampuan berpikir kreatif mahasiswa dalam merancang percobaan sederhana tentang pencemaran lingkungan berada pada posisi baik dan sangat baik. Model pembelajaran berbasis proyek melatih mahasiswa secara mandiri merumuskan masalah sampai dengan memecahkan masalah dengan percobaan sederhana yang dirancang dan menghasilkan karya yang nyata $^{16}$. Sehingga pembelajaran berbasis proyek ini akan lebih bermakna bagi mahasiswa dalam tiap tahapan berfikir kreatif yang diamati .

Tahap pertama adalah, membuat (generating), yaitu kemampuan dalam menganalisis masalah dan mengidentifikasi masalah lingkungan yang ada disekitar. Selama proses ini mahasiswa diminta untuk menentukan daerah yang dianggap telah

${ }_{16}$ Mukhayyaroh, I. A., \& Arief, S. (2018). Penerapan Project Based Learning Untuk Meningkatkan Kreativitas, Motivasi Belajar Dan Hasil Belajar. Economic Education Analysis Journal, 7(1), 1-14. 
tercemar (Air, udara dan tanah) dengan kriteria yang telah ditentukan. Selanjutnya mereka diminta untuk menjelaskan factor factor penyebab terjadinya pencemaran di daerah tersebut. Dari proses identifikasi masalah pencemaran, mahasiswa diminta untuk membuat rumusan masalah dan menjelaskan hipotesis dari rumusan masalah yang telah dibuat. Kemampuan dalam merumuskan hipotesis akan memberikan acuan mahasiswa dalam melakukan proses selanjutnya, Pada tahap membuat (generating) hampir semua mahasiswa mampu dengan sangat baik dalam menidentifikasi masalah pencemaran di lingkungan sekitar, serta merumuskan masalah dan hipotesis. Pada tahapan ini mahasiswa diminta untuk mempresentasikan hasilnya dan rata rata mahasiswa memiliki nilai 90 (sangat baik).

Tahap ke 2 dalam penelitian ini adalah merencanakan (planning). Pada tahap ini mahasiswa diminta untuk merancang langkah langkah proyek untuk membuktikan pencemaran yang terjadi pada lingkungan sekitar. Langkah langkah proyek dibuat berdasarkan rumusan masalah dan hipotesis yang telah disetujui sebelumnya. Alat dan bahan yang akan digunaka dalam proyek harus alat bahan sederhana dengan memperhatikan prinsif green chemistry. Berdasarkan hasil pengamatan pada tahap 2 ini, mahasiswa mampu merancang langkah langkah proyek untuk membuktikan hipotesis yang telah mereka buat. Kemampuan ini menggambarkan bahwa terjadi peningkatan kreatifitas mahasiswa. Pada proses perancangan yang baik akan mengembangkan proses berfikir kreatif ${ }^{17}$. Pada tahap ini nilai yang diperoleh adalah 88 dengan kategori sangat baik. Kemampuan berpikir kreatif itu dapat terlaksana dengan baik karena mahasiswa diberi kesempatan merancang sendiri langkah-langkah kerja proyek pencemaran lingkungan.

Memproduksi (producing) merupakan tahap ke 3 dari kemampuan berpikir kreatif. Pada tahap ini mahasiswa melaksanakan penelitian secara mandiri dengan tetap pendampingan jarak jauh dengan dosen pengampu. Pada tahap ini mahasiswa melaksanakan dan menulis data pengamatan serta mulai menganalisis dan membuat rancangan laporan penelitian. Berdasarkan hasil pengamatan pada tahap ini rata rata

\footnotetext{
17 Abdurrozak, R., \& Jayadinata, A. K. (2016). Pengaruh Model Problem Based Learning Terhadap Kemampuan Berpikir Kreatif Siswa. Jurnal Pena Ilmiah, 1(1), 871-880. https://doi.org/10.23819/pi.v1i1.3580
} 
nilai mahasiswa 88 termasuk kategori sangat baik. Hal ini disebabkan semua mahasiswa mampu melaksanakan penelitian dan mencatat hasil penelitiannya dengan sangat baik. Pada tahap ini terlihat kreatifitas mahasiswa dalam menyelesaikan permasalahan lingkungan sekitarnya. Proses kebebasan yang diberikan kepada mahasiswa dalam menyusun langkah langkah kerja dan mengamati secara mandiri dapat melatih kemampuan berfikir ${ }^{18}$.

Pelaksanaan penelitian yang dirancang sendiri menggunakan alat dan bahan sederhana dengan prinsif green chemistry. Hal ini akan membangkitkan kreatifitas mahasiswa dalam melakukan pengamatan mandiri. Pembelajaran berbasis proyek dapat melatih kemampuan berfikir kreatif mahasiswa dalam praktikum kimia lingkungan karena diminta mencari alternative bahan bahan yang ada di alam ${ }^{19}$.

Tahap ke 4 dalam penelitian ini adalah memeriksa (checking). Tahap ini dilakukan dengan melakukan presentasi hasil pengamatan mulai dari cara kerja, prosedur kerja dan hasil. selanjutnya dilakukan penilaian antar kelompok terhadap kualitas proyek yang telah dilakukan. Pada tahap ini diperoleh nilai rata rata 80 termasuk dalam kategori baik. Kategori baik menggambarkan mahasiswa sudah terbangun kreatifitasnya sehingga bisa menilai kelebihan dan kekurangan proyek kelompok lain. Penilaian antar kelompok dilakukan dengan kriteria yang telah ditentukan. Kriteria yang dijadikan patokan dalam proyek ini adalah, kesesuaian antara masalah dan langkah kerja, kesesuaian hasil dan hipotesis, literatur dalam pembahasan, alat dan bahan yang digunakan ramah lingkungan. Kriteria yang diberikan dalam proses penilaian akan melatih keterampilan berfikir kreatif. Menurut Anderson \& Krathwohl ${ }^{20}$, proses penilaian yang bertujuan menilai kekurangan dan kelebihan suatu hasil akan melatih tingkat berfikir.

18 Rahmawati, A., \& Purnomo, E. A. (2017). Penerapan Pjbl Untuk Meningkatkan Kemampuan Berfikir Kreatif Pada Workshop Pendidikan Matematika. Prosiding Seminar Nasional Dan Internasional, 25-34. https://jurnal.unimus.ac.id/index.php/psn12012010/article/view/3035

19 Davis, Eric J.; Pauls, Steve; Dick, J. (2017). Project-Based Learning in Undergraduate Environmental Chemistry Laboratory: Using EPA Methods To Guide Student Method Development for Pesticide Quantitation. J. Chem. Educ, 94(4), 451-457.

20 Wilson, L. O. (2016). Anderson and Krathwohl Bloom's Taxonomy Revised; Understanding the New Version of Bloom's Taxonomy. The Second Principle, 1-8. https://thesecondprinciple.com/essential-teaching-skills/blooms-taxonomy-revised/ 
Tahap selanjutnya adalah mengkritik (critiquing). Setelah tahap penilaian, tahap ini menuntut mahasiswa lain dapat memberikan masukan atau saran terhadap hasil proyek teman lainnya. Sehingga mahasiswa bisa bertanggungjawab atas penilaian yang diberikan dan mampu memberikan masukan jika ada kekurangan pada penilain. Secara keseluruhan rata rata mahasiswa mampu memberi masukan dan saran pada karya temen yang lain pada kategori baik (78). Pada tahap ini mahasiswa dituntut untuk menilai hasil produk dari kelompok lain dan setelah itu memperbaiki produk sesuai dengan saran dari kelompok lain. Secara keseluruhan tahap ini didapatkan nilai rata-rata sebesar 78 dan termasuk dalam level 4 dengan kategori baik, artinya mahasiswa mampu melakukan penilaian sendiri dan mempertanggungjawabkan hasil dari penilaian tersebut.

Pembelajaran berbasis proyek pada matakuliah kimia lingkungan berjalan dengan sangat baik, mahasiswa sangat antusias membuat proyek yang mereka susun sendiri,dan telah melewati tahapan tahapan berfikir kreatif. Berdasarkan tahapan tahapan berfikir kreatif mahasiswa kimia lingkungan berada pada kategori baik sampai dengan sangat baik. Hasil penelitian ${ }^{21}$, menunjukan bahwa pembelajaran berbasis proyek mampu meningkatkan kreativitas peserta didik 31,1\%. Selain itu pembelajaran berbasis proyek memberikan kesempatan kepada mahasiswa untuk mengungkapkan ide serta gagasan gagasan sederhana sehingga dapat melatih kreativitas. Dari gagasan mahasiswa secara berkelompok diakhir perkuliahan didapatkan laporan tentang beberapa pencemaran lingkungan disekitar mereka, serta proses terjadinya pencemaran dan saran proses penanggulangan pencemaran.

\section{KESIMPULAN}

Pembelajaran berbasis proyek pada materi pencemaran lingkungan dapat meningkatakan aktivitas dan kreatifitas mahasiswa kimia lingkungan. Aktivitas ini terlihat dari antusias setiap mahasiswa dalam menyelesaikan proyek yang diberikan dari awal hingga selesai. Kreatifitas mahasiswa juga muncul dengan sangat baik dalam

\footnotetext{
${ }^{21}$ Insyasiska, D., Zubaidah, S., \& Susilo, H. (2015). Pengaruh Project Based Learning Terhadap Motivasi Belajar, Kreativitas, Kemampuan Berpikir Kritis, Dan Kemampuan Kognitif Siswa Pada Pembelajaran Biologi. Jurnal Pendidikan Biologi, 7(1), 9-21. https://doi.org/10.17977/um052v7i1p9-21
} 
proses proyek yang diberikan. Mulai dari tahap pertama, mahasiswa bisa mengidentifikasi masalah pencemaran dilingkungan sekitar dan bisa merumuskan masalah dan hipotesis dengan sangat baik. Tahap 2, mahasiswa mampu merencanakan/planning dengan sangat baik langkah langkah yang akan dilakukan untuk membuktikan terjadinya pencemaran dilingkungan sekitar. Tahap selanjutnya mahasiswa mampu melaksanakan proyek dengan sangat baik. Melaporkan hasil dengan presentasi dengan baik serta mampu memberikan kritikan dan masukan dalam setiap tahap proyek yang dipresentasikan kelompok lain dengan baik juga.

\section{DAFTAR PUSTAKA}

Abdurrozak, R., \& Jayadinata, A. K. (2016). Pengaruh Model Problem Based Learning Terhadap Kemampuan Berpikir Kreatif Siswa. Jurnal Pena Ilmiah, 1(1), 871-880. https://doi.org/10.23819/pi.v1i1.3580

Arikunto, S. (2010). Dasar-Dasar Evaluasi Pendidikan. Jakarta: Bumi Aksara, 2012.

Avellar, Isa G.J. de; Cotta, Tais A.P. G.; Neder, A. de V. F. (2012). Using Artificial Soil and Dry-Column Flash Chromatography To Simulate Organic Substance Leaching Process: A Colorful Environmental Chemistry Experiment. J. Chem. Educ., 89(2), 248-253.

Azis, A. (2020). Pengaruh Kinerja Guru Dan Pendayagunaan Pada Bidang Studi Pendidikan Agama Islam Dismp Swasta Se-Kecamatan Bukit Raya Kota Pekanbaru. 8(November), 210-243.

Davis, Eric J.; Pauls, Steve; Dick, J. (2017). Project-Based Learning in Undergraduate Environmental Chemistry Laboratory: Using EPA Methods To Guide Student Method Development for Pesticide Quantitation. J. Chem. Educ, 94(4), 451-457.

Farida, I. (2017). Evaluasi Pembelajaran. Bandung: PT. Remaja Rosdakarya, 2017.

Gunter, Tugce; Akkuzu, Nalan; Alpat, S. (2017). Understanding 'green chemistry' and 'sustainability': an example of problem-based learning (PBL). Research in Science \& Technological Education, 35(4), 500-520.

Insyasiska, D., Zubaidah, S., \& Susilo, H. (2015). Pengaruh Project Based Learning Terhadap Motivasi Belajar, Kreativitas, Kemampuan Berpikir Kritis, Dan Kemampuan Kognitif Siswa Pada Pembelajaran Biologi. Jurnal Pendidikan Biologi, 7(1), 9-21. https://doi.org/10.17977/um052v7i1p9-21

Juniarso, T. (2020). Model Challenge Based Learning Terhadap Kemampuan Berpikir Kreatif Mahasiswa. Jurnal Pendidikan - Teori, Penelitian, Dan Pengembangan, 5(1), $36-43$.

Lasker, G. A., \& Brush, E. J. (2019). Integrating social and environmental justice into the chemistry classroom: a chemist's toolbox. Green Chemistry Letters and Reviews, 12(2), 168-177. https://doi.org/10.1080/17518253.2019.1609602 
Manahan, E. S. (2010). Enviromental Chemistry. 9th ed. USA: CRC Press.

Mukhayyaroh, I. A., \& Arief, S. (2018). Penerapan Project Based Learning Untuk Meningkatkan Kreativitas, Motivasi Belajar Dan Hasil Belajar. Economic Education Analysis Journal, 7(1), 1-14.

Rahmawati, A., \& Purnomo, E. A. (2017). Penerapan Pjbl Untuk Meningkatkan Kemampuan Berfikir Kreatif Pada Workshop Pendidikan Matematika. Prosiding Seminar Nasional Dan Internasional, 25-34. https://jurnal.unimus.ac.id/index.php/psn12012010/article/view/3035

Ryu, Minjung; Nardo, J. E. . M. W. . M. Y. (2018). An examination of preservice elementary teachers' representation about chemistry in an in an intertextualityand modeling-based course. Chemistry Education Research and Practice, 19(3), 681693. doi: 10.1039/C7RP00150A

Sani, R. A. (2014). Pembelajaran Saintifik untuk Implementasi Kurikulum 2013. Jakarta: Bumi Aksara.

Santyasa, I. W. (2004). Model problem solving dan reasoning sebagai alternatif pembelajaran inovatif. Makalah. Disajikan dalam Konvensi Nasional Pendidikan Indonesia V. Bali: IKIP Negeri Singaraja.

Sastrika, I. A. K., Sadia, I. W., \& Muderawan, I. W. (2013). Pengaruh model pembelajaran berbasis proyek terhadap pemahaman konsep kimia dan keterampilan berpikir kritis. E-Journal Program Pascasarjana Universitas Pendidikan Ganesha, 3(2), 194-204.

Sevian, H., \& Talanquer, V. (2014). Rethinking chemistry: A learning progression on chemical thinking. Chemistry Education Research and Practice, 15(1), 10-23. https://doi.org/10.1039/c3rp00111c

Sugiyono. (2017). Metode Penelitian Kuantitatif, Kualitatif dan R\&D. Bandung: CV. Alfabeta.

Wilson, L. O. (2016). Anderson and Krathwohl Bloom's Taxonomy Revised; Understanding the New Version of Bloom's Taxonomy. The Second Principle, 18. https://thesecondprinciple.com/essential-teaching-skills/blooms-taxonomyrevised/ 